\title{
Ranskalaisen strukturalismin kaari
}

Fransçois Dosse: Strukturalismin historia. Osa I. Ohjelman synty 1945-1966. Alkuperäisteos Histoire du structuralisme, tome 1: Le champ du signe 1945-1966 1992. Suomentanut Anna Helle. Helsinki: Tutkijaliitto 2011. 451 s. ISBN 978-952-5169-70-6.

Fransçois Dosse: Strukturalismin historia. Osa II. Joutsenlaulu 1967-. Alkuperäisteos Histoire du structuralisme, tome 2: La chant du cygne 1967 à nos jours 1992. Suomentanut Anna Helle. Helsinki: Tutkijaliitto 2018. 531 S. ISBN 978-952-7093-13-9.

Strukturalismilla tarkoitetaan lähinnä Ranskassa 1950-1990-luvuilla vallinnutta ihmistieteiden suuntausta, jossa keskiössä oli tutkimuskohteen rakenne. Tällaisessa tutkimuksessa olennaista oli subjektin häivyttäminen, historiallisen näkökulman välttäminen sekä pysyttäytyminen systeemin sisäisissä lainalaisuuksissa. Esimerkiksi antropologisessa myyttien tutkimuksessa keskeistä oli myyttien keskinäisen koodiston sisäinen rakenne, ei se, mitä niillä viestitään. Myyttien tutkimuksen lisäksi strukturalismi oli muun muassa alitajuisten ilmiöiden sekä kaunokirjallisten teosten, yhteiskunnan ja kielen rakenteen tutkimusta.

Strukturalismi oli myös vasemmistolainen poliittinen liike, joka pyrki muuttamaan yliopistolaitosta ja yhteiskuntaa. Vasemmistolaisia strukturalisteja olikin 1960-1980-lukujen ihmistieteiden tutkijoista todella merkittävä määrä. Teoreettisesti sitovaa yhteyttä ei vasemmistolaisuuden ja strukturalismin välille kuitenkaan saatu luoduksi, sillä vaikka Karl Marxin teorioista lähtien ja niitä muunnellen tutkittiin yhteiskunnan alistavia rakenteita, ei kestävää strukturalistista vasemmistolaista yhteiskuntateoriaa syntynyt yh- teiskunnallisen ja kulttuurisen eriarvoisuuden tavattoman monitahoisuuden takia. Joka tapauksessa huomattavan monet strukturalistit olivat sorrettujen asialla, monesti käytännössäkin. Esimerkiksi Michel Foucault puolusti ja auttoi vankeja, Claude Lévi-Strauss alkuperäiskansoja, ja useimmat kannattivat Vietnamin ja Algerian sotien itsenäisyystaistelijoita.

Fransçois Dosse (s. 1950) on ranskalainen nykyhistorian professori IUFM de Créteil -yliopistossa. Hänen erityisenä kiinnostuksen kohteenaan on strukturalismi teoreettisena ja poliittisena liikkeenä. Hän on myös elänyt strukturalistisen tieteen huippuvuoden 1966 ja sitä seuranneen kiivaan vaiheen sekä kokenut toukokuun 1968 Ranskan opiskelijamellakat, joilla yliopistolaitos ja yhteiskunta todella haastettiin. Ja hän näki, kuinka elokuussa 1968 Varsovan liiton sotavoimat murskasivat Prahan kevään, jolloin strukturalismin nimissä ollut poliittinen toive taittui.

Strukturalismin aatehistorialliset juuret olivat selkeimmin Ferdinand de Saussuren kielen rakennetta ja synkroniaa korostavissa näkemyksissä. 1960-lukua edeltävää filosofista kontekstia, jonka strukturalistit kokivat konservatiiviseksi ja kahlehtivaksi, olivat "metafysiikka", Hegelin dialektiikka, Husserlin fenomenologia, Sartren eksistentialismi, hermeneutiikka ja analyyttinen filosofia. Myös kehittyvät ihmistieteet, kuten sosiologia ja antropologia sekä kirjallisuustiede ja psykoanalyysi sekä edelleen jopa taloustiede, maantiede ja elokuvatutkimus, imivät strukturalismin näkökulmaa alansa teoreettista tasoa kohottamaan. Tästä voi jo aavistaa, että strukturalismissa on merkittävää alojen välistä vaihtelua. Eikä vaihtelu siihen lopu: Dosse mainitsee strukturalismin 
myös muun muassa metodiksi, näkökulmaksi, tutkimusotteeksi, teoriaksi (spesifisti ja yleensä) ja ihmistieteiden yleiseksi ohjelmaksi, minkä lisäksi hän rinnastaa sen monessa yhteydessä filosofiaan. Semiotiikan, siis yleisen merkkitieteen, ja strukturalismin suhde pysyy ratkaisemattomana. Kysymys kuuluu, onko semiotiikka strukturalismin haara vai päinvastoin. Dosse ottaa kysymykseen implisiittisen kannan ja esittelee semiotiikan keskeisen teoreetikon, pariisilaistuneen Algirdas Greimasin lähinnä strukturalististen ideoiden kehittelijänä.

Kuten tutkimuksessa yleensä, metodi ontologisoituu helposti. Dosse antaa useita esimerkkejä siitä, kuinka aluksi metodisena välineenä ollut rakenne hahmottaa tutkimuskohdetta on muuttunut maailmassa olevaksi tutkimuskohteen olemukseksi. Tällöin rakenne on muuttunut tutkimuksen itseisarvoiseksi perustaksi ja tavoitteeksi. Strukturalismi määrittyi myös tieteensosiologisesti: strukturalismia oli se, minä strukturalisteiksi itseään kutsuvat strukturalismina pitivät. Sisällöt ja kohteet olivat jatkuvassa muutoksessa, ja koko ajan käytiinkin keskustelua siitä, mitä oli strukturalismi ja ketkä olivat strukturalisteja. Ja kuten edellä jo ilmeni, strukturalismi oli myös liike, joka varsinkin alkuvaiheessaan olennaisesti määräytyi konservatiivisen tieteen ja politiikan vastustuksena. Yleensä voi huomata, että se, mitä strukturalismina pidetään, on enimmäkseen muuta kuin lingvistiikkaa. Lingvistinen strukturalismi taas on elänyt omaa elämäänsä - esimerkiksi monella taholla muuttunut funktionalismiksi. Ja vaikka foneemi onkin ollut muilla aloilla mallina invariantista eli struktuurissa olevasta vaihtelemattomasta ja abstraktista yksiköstä, vaikkapa morfofoneemilla ei liene ollut merkittäviä vastineita lingvistiikan ulkopuolella.

Dossen kaksiosainen teos esittelee laajasti strukturalismin syntyä, asemaa, sisältöä ja kuolemista. Teos ilmestyi aika pian strukturalismin huippuvaiheen laannuttua, mutta suomennokset vuosilta 2011 ja 2018 ovat hieman myöhästyneet alan jälkikeskustelusta. Dossen esitys on kronologinen. Ensimmäisessä osassa selvitetään Ranskan tieteen ja yhteiskunnan jähmettyneeksi koettua tilaa, jossa strukturalismi versoi. Osa käsittelee myös strukturalismin nousun ja ulottuu sen huippuun 1960-luvun loppupuolelle. Toisessa osassa tarina jatkuu kriisien ja kuihtumisen kuvaamisena 1990-luvun alkuun asti. Kaiken aikaa on puhe strukturalismin perusoletuksista, asetelmista ja tavoitteista yleisesti ja oppialakohtaisesti sekä niiden muutoksista. Teos kertoo myös henkilöistä, tapahtumista, akateemisen maailman murroksesta sekä vilkkaasta kirjoittelusta ja kiistelystä lehdistössä. Kuvaus poliittisesta strukturalismista on vaikuttava kertomus Ranskasta, kuusikymmenluvusta, politiikasta, toivosta ja sen menetyksestä, teoreettisesta ailahtelevaisuudesta, tieteen ja tiedon sosiologiasta. Vain osa tuosta kaikesta liittyy kielitieteeseen. Mutta kuten teoksessa moneen otteeseen painokkaasti todetaan, kielitiede oli jatkuvasti olennainen pilottitiede ja kielitieteestä kaikki alkoi. Seuraavassa tarkastelen Dossen teosta kielentutkimuksen näkökulmasta.

\section{Taustaa ja vauhtia kielentutkimuksesta}

Kielessä on helposti havaittavaa rakennetta arkikeskusteluista teksteihin. Kielitieteilijöille rakenteen tutkiminen tarjoutuu kuin itsestään, ja kielioppeja onkin kirjoitettu jo yli parin vuosituhannen ajan. Strukturalismilla teoreettisena lingvistisenä paradigmana on kuitenkin spesifi merkitys ja alku: 1916 postuumisti julkaistu de Saussuren Course de linguistique général.

Strukturalismi oli muutamassa suhteessa antiteesi edellisen vuosisadan diakroniselle lingvistiikalle ja sen ato- 
mistiselle äännehistorialle. Strukturalismin lähtökohtana oli eristetty rakenne, de Saussuren langue, kieli puhunnasta ja muutoksesta abstrahoituna systeeminä, sekä kaksijakoinen kielellinen merkki. Strukturalismista tuli kielitieteen valtavirtaa Euroopassa ja pian Yhdysvalloissakin. Euroopassa se kukoisti kolmessa paikassa: Genevessä vaalittiin de Saussuren perintöä, ja sieltä strukturalismi levisi ranskankieliseen maailmaan. Prahan piirissä tutkittiin erityisesti fonologiaa mutta myös tekstien rakennetta venäläisen kirjallisuudentutkimuksen formalistisen koulukunnan jalanjäljissä. Keskeisiä toimijoita olivat venäläiset emigrantit, etunenässä N. S. Trubetzkoi ja Roman Jakobson. Ennen toista maailmansotaa Jakobson siirtyi muun muassa Pariisin kautta Yhdysvaltoihin. Hän oli monen tuttu, ja hänen kauttaan Prahan piirin ajatukset levisivät tehokkaasti. Kolmas strukturalismin keskus oli Kööpenhamina, jossa vaikutti Louis Hjelmslev. Siellä lingvistinen strukturalismi kehittyi abstrakteimpaan ja formalistisimpaan muotoonsa. Hjelmslevin oppeja sovelsivat semiootikko Algirdas Greimas ja filosofi Jacques Derrida. On hieman makuasia, onko Noam Chomskyn generatiivinen transformaatioteoria ja siitä alkanut perinne strukturalismia. Se on siitä peräisin, sillä amerikkalainen strukturalistinen syntaksi oli kehittynyt pitkälle transformaatioteorian suuntaan erityisesti Chomskyn opettajan Zellig Harrisin ansiosta. Chomsky on kuitenkin halunnut erottautua juuristaan klassisessa amerikkalaisessa strukturalismissa, jossa keskeistä oli kielen yksilöiden distribuutioiden määrittäminen, ja hän on korostanut itsenäisyyttään ajattelijana. Transformaatioteoriastakin Dosse toteaa, että se oli muilla aloilla monesti pilottitiede, sillä joka tapauksessa generatiivinen teoria ja sen syvärakenteet levisivät muihin tieteisiin 1960-1980-luvuilla. Esimerkiksi antropologiassa hahmoteltiin syvärakenteiden tapaisia kulttuurisia uni- versaaleja, ja psykologiassa - kuten kielitieteessäkin - syvärakenteet olivat ainakin jossain mielessä analogisia nykytieteen kognitioille, ja lisäksi niillä oletettiin olevan vastineita aivojen neurologisessa rakenteessa.

Fonologiassa saatiin aikaan kaunista ja yleistämiskelpoista teoriaa. Dosse mainitsee toistuvasti fonologian malliksi eri tieteenalojen strukturalisteille, esimerkiksi kirjallisuudentutkija Roland Barthesille, psykoanalyytikko Jacques Lacanille ja yhteiskuntateoreetikko Louis Althusserille. Lacan etsi rakenteita tiedostamattomasta, Barthes kaunokirjallisuudesta, ja Althusser koetti yhdistää strukturalismia ja marxilaisuutta yhteiskuntateoriassaan. Antropologi Lévi-Strauss keskittyi myyttien koodin tutkimukseen, ei niinkään viestin. Hän adoptoi de Saussuren muotomerkitys-dikotomian ${ }^{1}$ perustavana lähtökohtana antropologiaan. Muoto eli merkitsin asetettiin keskiöön, jolloin systeemin sisäiset ilmiöt tulivat hallitseviksi ja viittauskohde (tarkoite) jäi sivuun. Dosse näyttää myös strukturalismissa ilmenevän eksaktisuuden kaipuun, mikä näkyi esimerkiksi fonologiassa sekä strukturalismin myöhäisvaiheessa viehtymyksenä kybernetiikkaan eli itseohjautuvien systeemien tutkimiseen ja kehittelyyn, jossa ihminen nähtiin automaattisena systeeminä. Strukturalismi tavoitteli kolmannen tien asemaa ihmistieteiden ja eksaktien tieteiden välissä.

Yhteys strukturalistiseen kielitieteeseen loppuu monessa suhteessa tähän, sillä tiedostettuja teoreettisia strukturalistisia analogioita kielitieteen ja muiden tieteiden välillä ei Dosse juuri osoita. Pitkin matkaan Dosse kuvailee strukturalismille ohjelmaa, jollaista ei kielitieteessä ole. Sen mukaan strukturalismi merkitsi epäilyn filosofiaa ja paljastamisen paradigmaa, sivilisaation kuristavuuden purkamista ja

1. Ihmistieteissä tästä käytetään yleensä termiparia merkitsin-merkitty. 
merkityksen horjuttamista etsimällä sanotun takaa ilmausta vilpillisyydestä.

\section{Strukturalismin taustaa Ranskassa}

Strukturalismin alkuvaiheessa toinen maailmansota oli lähellä, mikä tuntui Ranskassakin kaikessa. Dosse mainitsee strukturalisteista heidän osansa vastarintaliikkeessä, vangittuina tai maanpaossa. Tämä oli monelle syy jonkinsuuntaiseen radikalisoitumiseen. Meneillään oli myös Ranskan kolonialismin pitkällinen ja repivä päättymisprosessi. Katkerissa sodissa muun muassa Vietnam ja Algeria irtosivat Ranskasta.

Vasemmistolaisuus oli strukturalisteille toivon ja tasa-arvon liike. Kuitenkin muun muassa Stalinin kuolemaa 1953 seuranneet paljastukset maan synkästä sisäpolitiikasta, sosialististen maiden monet vaikeudet ja viimeisenä Prahan tapahtumat 1968 hajottivat vasemmistoa esimerkiksi suhteessa uskollisuuteen Neuvostoliiton kommunistista puoluetta kohtaan. Sodan jälkeen varsin vahvassa Ranskan kommunistisessa puolueessa oli myös omia eripuraisuuksia. Maolaisuuskin sai jopa Kiinan kulttuurivallankumouksen aikana 1960-luvulla useita kannattajia strukturalistien keskuudessa.

Dossen mukaan "elitistisellä ja perinteiltään halveksitulla" Sorbonnen yliopistolla oli tieteessä valta-asema. Se oli tieteellisestikin konservatiivinen; Dossen sanoin se oli positivismin, atomismin, filologian mutta toisaalta hieman ristiriitaisesti myös idealismin ja hegeliläisen dialektiikan vallassa.

1960-luvun puolivälissä Sorbonnen rajaton valta alkoi murtua ja yliopistot modernisoitua. Painetta toivat myös opiskelijatulva, uudet yliopistot sekä se, että yliopistojen nähtiin kouluttavan lähinnä teknokraatisia virkamiehiä. Toukokuun 1968 opiskelijalevottomuuksissa strukturalisteilla oli keskeinen rooli haastettaessa klassisen humanismin vanhanaikaisiksi koettuja aloja. Historian, filosofian ja psykologian tuli antaa tilaa antropologialle, psykoanalyysille ja kielitieteelle, sillä "ihmistieteet eivät olleet vielä onnistuneet kokonaan vapautumaan pysähtyneen, bonapartistisen ja keskusjohtoisen valtion ja toisaalta perinteeseen sulkeutuneen Sorbonnen takia" (II s. 153).

Kielentutkimuskin oli klassisella kannalla, eikä moderni kielitiede ollut saavuttanut asemia instituutioissa etenkään Sorbonnessa. Yhdysvalloista Ranskaan 1955 palannut André Martinet oli ennestään ainoita vaikutusvaltaisia strukturalistisia lingvistejä Émile Benvenisten rinnalla. 1960-luvulla perustettiin yleisen kielitieteen laitoksia ja niissä avautui virkoja myös strukturalisteille. Yleisen kielitieteen kurssien myötä strukturalismista tuli suosittua.

Strukturalismilla käytiin vanhaa valtaa vastaan, mutta radikalismi meni nopeasti aika pitkälle, kuten seuraavasta ajalle tyypillisestä esimerkistä ilmenee (II s. 166): "Kielitieteen laitosta Nanterressa johtivat kommunistisen puolueen jäsenet, mutta Jean Dubois [kommunisti, strukturalisti, laitoksen johtaja] takasi, että laitos oli avoin kielitieteen suuntauksille". Poikkeuksellisen avarakatseinen Dubois ei rajoittanut rekrytointia vain kommunisteihin, ja suuri laitos keskittyi sosiolingvistiikkaan, joka ei ollut klassisen saussurelaista. Tutkittiin sanastollista vaihtelua, koodin ja sisällön eroja diskursseissa ja niiden vaihtelua diskurssien välillä, pyytämisaktin illokutiivisia sävyjä ja vallitsevaa poliittista diskurssia korkean poliittisen tietoisuuden aikana. Poliittista kielenkäyttöä tutkittiin paljon. Näihin aikoihin generatiivinen transformaatioteoria alkoi tulla tutuksi Ranskan kielitieteessä. Vaikka kielitiede siis pysyi mallin asemassa, de Saussuren ideoihin perustuvan klassisen strukturalismin ala oli tältäkin osin kaventumassa.

Dossen teoksesta näkyy ranskalaisen - enimmäkseen pariisilaisen - strukturalismin sisäänpäinkääntyneisyys ja itse- 
riittoisuus. Ranskalaisuutta on sekin, että paljon tapahtui yliopistojen ulkopuolella. Kaiken aikaa syntyi uusia lehtiä, ja niissä käytiin erittäin vilkkaita ja monipuolisia väittelyitä. Tieteenalojen rajat ja poliittiset näkemyserot ylittyivät monesti näissä väittelyissä. Esimerkiksi psykoanalyytikot ja kielitieteilijät kirjoittivat toistensa lehtiin, ja kommunistilehdissä oli tilaa strukturalisteille ja heidän kriitikoilleen. Myös päivälehdissä ja joskus televisiossakin strukturalismi sai näkyvästi huomiota. Dosse tiivistää dramaattisesti (I s. 335): "Näkyi 196o-luvun strukturalistinen kuohunta, sen kaukaisimmat tavoitteet, radikaaleimmat tiedeuskovaiset, sen elitistisen avantgarden ja massan dialektiikka, joka väitti puhuvansa maailmanlaajuisen proletariaatin nimissä ja oikeuttavansa näin mitä terroristisimmat ja terrorisoivimmat käytäntönsä."

\section{Mitä näkyy ja voi päätellä?}

Koska kielelliset konventiot ovat suhteellisen vakaita ja selvemmin nähtävissä kuin muut sosiaaliset konventiot, strukturalismin historiassa kielitiede oli moneen otteeseen pilottitieteen asemassa. Kielioppeja on kirjoitettu kauan, mutta esimerkiksi sosiologiassa, antropologiassa tai kirjallisuustieteessä kieliopin kaltainen kuvaus pysyy haaveena. Kielitieteen pilottiasemasta voi päätellä myös, että kielitieteelliset teoriat ovat ainakin jossain vaiheessa olleet solideja ja sopivan yleisiä. Teorianmuodostus ihmistieteissä on vaikeaa, sillä ihminen ja elämä mutkikkuudessaan eivät helposti alistu suurten yleistysten ja vahvojen väitteiden mukaiseksi. De Saussuren muotoilemat dikotomiat ja Jakobsonin binääriset oppositiot abstrahoituivat kielen tutkimuksessa selkeiksi. Kielitieteestä riippumattomina yleisinä käsitteellisinä välineinä ne olivat ihmistieteissä laajalti sovellettavissa. Generatiivisen transformaatioteorian syvärakenne teoreettisessa kehyksessään oli lupaavan metaforinen abstraktio ihmismielen syvimpien rakenteiden kuvaajille. Se, että tuollaiset ideat lopulta kumoutuvat empiirisessä tutkimuksessa kaukana lähtökohdastaan, ei osoita niiden heikkoutta vaan päin vastoin. Ne ovat olleet selkeitä viitekehyksiä, joissa toimia, ja niiden koetteleminen on ollut askel parempaan ymmärrykseen ja uusiin kysymyksenasetteluihin monilla tieteenaloilla. Kielitieteilijä on nojatuolistaan saanut nähdä alansa suurten ajatusten vaeltelua ihmistieteissä.

Dossen teoksesta ilmenee, miten vaikuttavaa strukturalismi oli Ranskassa. Strukturalismin aikainen Ranska tarvitsi muutosta, ja tiede oli keskeinen konstituentti sekä Ranskassa että sen muuttamisessa. Maa on iso ja vanha, joten tutkijoiden oma yhteisö riittää tuottamaan tarpeeksi tieteellisiä uudennoksia ja kuohuntaa. Muun maailman kanssa saattoi olla vuorovaikutuksessa aika valikoiden.

Suomalainen kielentutkimus on ottanut ranskalaisesta strukturalismista verrattain vähän vaikutteita. Poliittinen liikehdintä Suomessa ei ole kulkenut strukturalismin kautta, ei kielentutkimuksessa eikä muutenkaan. Tässä mielessä suomalainen kielentutkimus on ollut enimmäkseen puolueetonta, vaikka ideologista taustaa on toki aina ollut. Esimerkiksi fennistiikassa on ollut vahva käsitys ideaalisesta agraarisuomesta aidoimpana suomena. Aikanaan Neuvostoliitto oli voimakas, ja siellä asui alistettuja sukukansoja, ja Suomessa piti tarkoin harkita, mitä niistä sanottaisiin. Ja Suomessakin oli radikaali opiskelijaliike, jopa muun muassa Helsingin yliopiston fennistiopiskelijoiden ainejärjestössä Siulassa. Fennistiikan ja fennougristiikan poliittinen historia vaatisi oman tutkimuksensa toisen maailmansodan jälkeisiltä ajoilta. Se olisi hyvin erilainen kuin Dossen kertomus ranskalaisesta strukturalismista.

Dosse on antanut teossarjansa ensi osalle alaotsikon "Ohjelman synty" ja toiselle "Joutsenlaulu", aivan kuin struktura- 
lismi olisi syntynyt, kukoistanut ja kuollut. Strukturalismi kyllä taantui ja useimmat keskeiset strukturalistit kuolivat traagisesti 1980-luvulla, mutta rakenteita ei ole hylätty tai kielletty, eikä niiden muutoksiakaan. Teoksensa lopuksi Dosse esittelee edelleen elävää strukturalismia, sen sopeutuneita ja sulautuneita muotoja muun muassa neurotieteiden ja automaattisen tietojenkäsittelyn uusissa ympäristöissä. Strukturalismin tuloksia ja tulevien sukupolvien kumottavia tai palautettavia aiheita ovat esimerkiksi diskurssi jalostuneena kaikista sen määritelmää, rajoja, omalakisuutta, alitajuisuutta, poliittisuutta ynnä muuta koskevista väittelyistä, mihin se Foucault'lta, Derridalta ja Barthesilta jäi. Muiden muassa he kävivät antaumuksellisia keskusteluja diskurssista sitoutuen sekä strukturalististen ajatusten(sa) konstruoimiseen että dekonstruoimiseen. Itseäänkään säästämättä he jättivät kuitenkin perinnöksi parempaa ymmärrystä diskurssista. Muuta hyödyllistä perintöä on esimerkiksi Foucault'n tiedon arkeologia tai intertekstuaalisuus Julia Kristevan ${ }^{2}$ jäljiltä. Ihmistieteiden strukturalismin yleiseen elinkaareen verrattuna kielitieteellinen rakenteen tutkimus on aika vakaata antiikista tulevaisuuteen.

Rakenteiden tutkimuksen kuvaaminen on käsitehistoriaa, jossa moni asia poistuu ja toistuu, mutta ei entisenä, ja jossa todelliset käänteet eivät ole äkkinäisiä. Dossen teoksista näkee myös tieteen sosiaalista aaltoilua. Vaikka tieteessä isot asiat muokkautuvat hitaasti, jokaisen sukupolven, tiedeyhteisön ja jopa jokaisen tutkijan on ne itse sisäistettävä ja kielennettävä. Tämä liike on nopeampaa, sillä siinä tuntuvat ajankohtaiset poliittiset ja kulttuuriset suhdanteet. Dossen teos on

2. Intertekstuaalisuus ranskalaisessa strukturalismissa on peräisin Mihail Bahtinilta. Välittäjinä toimivat Bulgariasta emigroituneet Tzvetan Todorov ja Julia Kristeva. kertomus erottautumisen pakosta, hurjasta retkestä ja paluusta, missä strukturalismi näyttää toisaalta varoittavalta esimerkiltä ajattelussaan holtittomasti ryntäilevästä tiedeyhteisöstä, toisaalta taas rohkaisevalta esimerkiltä ennakkoluulottomuudesta ja toiveikkuudesta. Strukturalismiin suhdanteiden vaikutus oli erityisen painokasta ja välitöntä, mistä seurasi nopeita käänteitä eri tieteenaloilla. Tämä on tieteensosiologiaa, joka teoksessa kietoutuu käsitehistoriaan.

\section{Huomautuksia}

Teosten kokonaisuus on erittäin laaja sivuja on yhteensä lähes tuhat -, ja se sisältää tavattoman määrän lähteisiin ja haastatteluihin perustuvaa tietoa ihmisistä, tapahtumista ja instituutioista. Kiinnostavien yksittäisten tapausten ohella ja niitä yhdistääkseen Dosse tarjoaa runsaasti kiinnostavia synteesejä asioiden tilasta, muutosten suunnista ja suhdanteista tieteenaloittain, tieteiden välisesti ja suhteessa yhteiskuntaan. Tuo kaikki on vaatinut kirjoittajalta asiantuntemusta ja kykyä nähdä isoja asioita. Tarkastelu on monipuolista, ja se tasapainoilee eri näkökantojen välillä niin, ettei jälkiviisastelun vaikutelmaa juuri synny. Esimerkiksi Lévi-Straussiin keskittyvissä luvuissa näkyy sellaista systemaattisuutta, jota lingvistiikan historiankirjoituksesta puuttuu, Dossen sijoittaessa hänet ihmistieteiden kartalle funktionalismin, empirismin ja strukturalismin ristiaallokossa ja hetkittäin katsoessa hänet positivistiksi. Samaan tapaan sijoittuu sosiologi Pierre Bourdieu omalle paikalleen sekä tutkijayhteisön jäsenenä että tutkimuksensa sisällön suhteen.

Jotkut yleistykset strukturalismin vaiheista, käänteistä tai analogioista eri tieteiden välillä ovat kuitenkin epäuskottavan jyrkkiä ja kertakaikkisia, mikä saa strukturalistit näyttämään laumasieluilta. Esimerkiksi Dosse toteaa, että "[kirjalli- 
suudentutkimuksen alueella syntyneen dialogisuuden käsitteen osoittauduttua hedelmälliseksi] koko ranskalaisen pragmatiikan koulukunta omaksui anglosaksisen mallin mukaisesti tämän tutkimusotteen, mikä mahdollisti siihen asti hyljeksityn kielifilosofian kehittymisen" (II s. 425). Noin yhtenäistä ja selvää käännettä pragmatiikkaan tuskin tapahtui, ja edellä Dosse on itsekin useaan otteeseen puhunut pragmaatikko J. L. Austinista ja hänen aikaisemmin saamastaan huomiosta.

Strukturalistinen tutkijayhteisö näyttää Dossen esittelemänä täyttävän koko Ranskan ihmistieteet; muita suuntauksia ei juuri ole. Koska hän kuvaa ranskalaista tiedeyhteisöä strukturalismin piirin sisältä käsin, esimerkiksi Sorbonne on vain jähmeä, vanhanaikanen ja lähes nimetön, ja "konservatiivinen tiede" on lähinnä homogeeninen olosuhde ja hidaste strukturalismin vyöryvälle virralle. Toisaalta strukturalistinen tutkijayhteisö näyttää ailahtelevalta. Esimerkiksi kysymys siitä, millainen paino historiallisella näkökulmalla tai (tutkijan) subjektilla on humanistisissa tieteissä, on aivan keskeinen peruskysymys. Strukturalistit kuitenkin yrittivät ohjelmallisesti päästä historiasta eroon ja miettiä aikaa uudella tavalla. Muutamassa vuodessa historia sitten vääjäämättä palasi. Tässä valossa strukturalismi vaikuttaa avantgardistiselta ajatuskokeiden sarjalta ja tiedeyhteisö debattivetoiselta ideariiheltä, jolta puuttuu kärsivällisyys katsoa, mitä lähtöasetelmasta todella seuraa. Tällaista tuskin voi laittaa pelkästään ranskalaisten intellektuaalisen perinteen, yliopistolaitoksen ja 1960-luvun tiliin, vaan strukturalismin kiivaus, dynamiikka ja yhteiskuntasuhteet jäävät edelleen merkittävältä osaltaan suureksi haasteeksi tieteensosiologiselle tutkimukselle.

Dosse tuntee kielitieteestä lähinnä suuret linjat ja strukturalismiin sopivat piirteet. Tästä seuraa muutamissa kohdin karkeaa puhetta. Esimerkiksi hänen mukaansa "1970-luvun puolivälin jälkeen historismia ei enää kohdeltu erehdyksenä kuten oli tehty strukturalismin loiston aikaan. Eniten hämmästytti historiallisuuden paluu sellaisillekin tieteenaloille, kuten kielitieteeseen ja semiotiikkaan, jotka olivat kiistäneet sen pätevyyden." (II s. 431). Aivan liian jyrkkää, nimetöntä ja perustelematonta puhetta. Dosse on lukenut diakronisen kielitieteilijän de Saussuren kurssin synkronisen strukturalistin silmälasien läpi.

Dosse ei kaihda monisanaista kuvailua, mikä monesti estää vaikeaselkoista asiaa muuttumasta puisevaksi ja tekee oikeutta strukturalismin kiihkeälle poliittisuudelle. Tyyli on sisällöstä tinkimättä tärkeilemätöntä, kumouksellisen liikkeen henkeen sopivaa. Teos edellyttää lukijalta jonkin verran yleistietoa Ranskasta ja ihmistieteistä. Se sopii lukijalle, joka tuntee ainakin jonkin puolen strukturalismista, sillä kaikkea ei ole kerrottu alusta alkaen. Käännöskin on ollut valtava urakka. Se on huolellisesti tehty. Sananvalinnat ovat teoksen hengelle uskollisia, ja sanasto on paikoin yhteiskuntatieteiden tai peräti strukturalismin omaa. Esimerkiksi murtuma ja halkeama ovat teknisinä termeinä käytössä yleisempien taitekohdan tai käänteen käsitteiden sijaan. Arvattavasti tällaisten alkutekstin motivoimien sananvalintojen perustana ovat käytettyjen sanojen metaforiset konnotaatiot. Viittauskohde voisi kuitenkin monissa yhteyksissä olla tarkoite. Lausuma ja lausuminen ovat vaihtelevassa käytössä eri tutkijoilla, mutta niinhän ne ovat lingvistiikassakin. Tämä heijastaa sitä, että languen ja parolen suhde on suuri haaste kaikille strukturalisteille ja muillekin.

TAPANI KELOMÄKI etunimi.sukunimi@gmail.com

Kirjoittaja on suomen kielen yliopistonlehtori emeritus Helsingin yliopistossa. 